\title{
International Education Policies, Issues, and Challenges
}

\author{
Nicholas Burnett
}

\begin{abstract}
This short chapter discusses the rights and capabilities of, and development approaches to, education in developing countries, the recent evolution of developing countries' education systems in the present century, the 'leaderless globalisation' of the international institutions currently responsible for education, and the initial effects of the data and evaluation revolution on education. It concludes with five recommendations: evidence should be used more in education strategies, policies and practices; innovation needs to be encouraged; international funding should target more the neediest countries; assessment, benchmarking, and evaluation should be further encouraged; and a new international governance mechanism is needed for education, possibly led from outside the education sector itself.
\end{abstract}

Education post-2015 was discussed at the Global Education Meeting in Oman in May 2014, and there seems likely to be one broad international goal for education, focused particularly on learning at all levels of education and throughout life, measured by some ten or so targets. This new goal, and its associated targets, will therefore go well beyond the overlapping six Education for All (EFA) and two education Millennium Development Goals (MDGs) currently in place since 2000, which are mostly to do with access.

The effectiveness of any new education goal, however, will depend on the extent to which it is grounded in (1) a consensus on why education matters for development; (2) the recent history of enrolment, learning, and financing, including the growing importance of private as well as public education for the poor; (3) the international institutional environment, including new players, and the ability to monitor and enforce the goal; and (4) the application in education of the broader data and evaluation revolution that has impacted on development thinking and development economics.

(C) Graduate Institute of International and Development Studies, 2014 ～DOI 10.1163/9789004281158_003 This is an open access chapter distributed under the terms of the Creative Commons Attribution- 
For the EFA and MDGs set in 2000, the case for investing in basic education for all and basic schooling respectively rested largely on two planks. First, education, and especially elementary education, is a human right, enshrined in the 1948 Universal Declaration of Human Rights and many subsequent international and national documents, though taken together they do not clearly delineate exactly how many years of education are implied by its being a right that the state should ensure. Second, education results in increased productivity and leads to economic growth and so is essential for development. In particular, basic education was thought to be the priority, based on analyses that appeared to show that the rate of return to investments in primary education was higher than those in secondary and tertiary education. Even though these two planks each led to the same conclusion of the overarching importance of basic education, and thus could have been seen as complementary, in practice they were often presented as alternatives, respectively associated with the United Nations Educational, Scientific and Cultural Organization (UNESCO) and the World Bank. Frequent debates, in international meetings, about which plank was the fundamental reason for investing in education paradoxically undermined the powerful joint case that both could have made together. Echoes of these debates, which have not been helpful to the broader case that education must make against other priorities in international goal-setting, can be seen in Draxler's article in this volume (Chapter 3).

This state of affairs can be avoided with the post-2015 goals if it is recognised that the case for education has, since 1990, developed in three important directions, all of which are complementary if conceptually different:

a) The rights argument has been reinforced by the inclusion of education as a human right in the constitutions of major countries, such as India and Indonesia; by explicit statements by the World Bank, beginning under the Wolfensohn presidency, that education is a right, thereby reducing the artificial differences between the rights and economics arguments caused by their association with particular institutions; and by worldwide reaction to well-publicised attacks on education such as the shooting of the schoolgirl Malala Yousafzai in Pakistan in 2012 and the abduction of two hundred or more schoolgirls in northern Nigeria in 2014.

b) The rights and economics arguments have been complemented by a third and powerful argument from yet another perspective, that of capabilities as developed by Amartya Sen. Individuals can only reach their full 
potential (capability) if they are equipped by education to do so. This argument has not achieved as great a visibility as the other two arguments but it has been very important in influencing key debates and discussions. For example, the Education for All Global Monitoring Report has since its inception taken a 'rights, capabilities and development' approach (UNESCO, 2002).

c) The economic growth argument has grown into a broader development argument, based not only on the economic benefits of education but also on those of social cohesion and especially health. On the economic side, it has become clear that much more than simply access to basic education is important to economic growth and poverty reduction; secondary education and quality matter too. The returns to education have continued to be estimated but now show that those for secondary education are generally higher than those for primary education (see, for example, Psacharopolous and Patrinos, 2004; Colclough et al., 2009). The quality of education (as measured by scores on the international PISA assessment) is more important in determining economic growth than is simply the number of years spent in education (see, for example, Hanushek and Woessman, 2010). In addition, education has been shown to reduce poverty directly (Bird and Higgins, 2011). Beyond the economic effects, education has been shown to contribute to social cohesion in general (Heyneman, 2003) and specifically to lower crime rates (Soares, 2004) and greater civic engagement (Mertaugh et al., 2009). Education results in better decisions about maternal and child health (see, for example, Feinstein et al., 2006) and delays the age of marriage (Majgaarden and Mingat, 2012), reducing fertility and improving health generally.

Thus, the broad case for investing in education now has three rather than two planks, and each plank is much stronger than it was before. Moreover, these planks are complementary and together make an overwhelming case for educating all and, in particular, for focusing on learning as suggested by the work of Hanushek and Woessman (2010). However, this case will only be effective in education's competition, for attention and indeed resources, with other sectors if it is made in this coherent fashion and not partially undermined, as in the past, by unhelpful debates about which plank is of prime importance. All three matter.

Some of these debates continue, as noted in Chapter 1 of this volume, though there is a growing consensus around all three planks of rights, capabilities, and development that make the case for education. An interesting exception to this growing consensus is the new debate stimulated by the growth of private 
education for the poor (see Section 2 of this chapter), the pragmatic analysis of which is complicated by those opposing it on principle on rights grounds and those supporting it on principle on economic grounds. Neither seems very helpful in explaining why private education for the poor has expanded and what policy options are relevant.

2

\section{The Evolution of Education in Developing Countries Since 2000}

The education MDGs and the EFA goals are not going to be met by 2015 (UNESCO, 2013-which is also the source of data in this and the next two paragraphs). Nonetheless enormous progress has been made as documented by the EFA Global Monitoring Reports. Major achievements between 1999 and 2011 include pre-primary gross enrolments increasing from 33 per cent in 1999 to 50 per cent in 2011; a halving of the number of primary school aged children out of school to 57 million; the proportion of countries achieving universal primary enrolment rising from 30 per cent in 1999 to 50 per cent in 2011 ( for the 122 countries for which data exist); a vast expansion of secondary education with the gross enrolment rate increasing from 72 per cent to 82 per cent, including a doubling in sub-Saharan Africa to reach 49 per cent; major progress towards gender parity; government spending on education increasing from 4.6 per cent to 5.1 per cent of gross national product (GNP), with the increase being one full percentage point of GNP for low-income countries; and a steady increase in aid for education from 2002 to 2010.

Major problems nonetheless persist. The rate of decline in the numbers of children out of school has slowed, and such children are increasingly concentrated in conflict-affected countries where progress is difficult. The number of adult illiterates remains stubbornly constant at around 774 million, though the rate of illiteracy has declined slightly. Aid for education peaked in 2010 and has since declined, with the share of total education aid going to the neediest low-income countries being less than that going to middle-income countries.

Above all, however, there is now a general realisation, based on different sources of evidence, that many of those in school are not learning, or are not learning sufficiently. In one sense, this is not new knowledge, as discussed in Chapter 1 of this volume; in another it is, in that there is now an emerging consensus that something needs to be done about this 'learning crisis' and that efforts need to focus as much on learning as on access to education. There are today some 250 million primary and secondary school-aged children who are not able to read, write, or do basic mathematics - and 130 million of them are in school. Much other evidence, including from powerful citizen-led assess- 
ments in India, Pakistan, and East Africa, has highlighted this learning crisis. Learning is as much an equity issue as is enrolment, as those from more affluent backgrounds show higher levels of learning than do the poor and disadvantaged.

While skills for employability were included in the current EFA goals, if not in a well-defined way, they are not part of the current MDGs. This relative disregard of skills development is now changing and there has been a major renewal of interest in skills for employability, driven by the large youth 'bulge', by the global recession of 2008-11 with the consequent rise in unemployment, and by the increasing complaints of employers that school-leavers are not well equipped to join the workforce. Vocational education, and the need to link to employers, is very much back on the agenda having not featured strongly in 2000 when the present goals were set.

Yet it is surprising how little thinking has been devoted to meeting these new challenges. While most children now exit formal education with at least some secondary schooling, secondary education is less and less relevant, being generally still designed as a route towards higher education rather than one into the workplace. Indeed, education more generally remains a very conservative sector, largely doing things the way they have always been done, with insufficient innovation and adaptation to modern economies and societies. Innovation is not to be confused with technology, yet technology is the only area in which innovation is currently happening in education, with the growth of MOOCs and their applicability to higher education in developing countries.

In large part in response to the poor performance of the public sector in terms of both learning and relevance, there has been a major expansion of private education aimed at the poor. In urban India and in Lagos State in Nigeria, some 80 per cent of children now attend private schools (Day et al., 2014); about 80 per cent of pre-school age children in the slums of Accra, Johannesburg, Lagos, and Nairobi attend private preschools (Lowenstein et al., 2014). Chains of private schools for the poor are springing up, including, for example, Bridge International in Kenya and Omega in Ghana. The response of the education establishment to these developments has largely been to deplore them or to try to regulate them rather than to understand what has caused them in terms of poor parents' dissatisfaction with public education in many, though by no means all, countries.

These major developments in education in developing countries in this century are relatively absent from current discussions leading up to possible new international goals, with the important exception of the learning crisis which is now generally recognised. Even here, however, institutional developments 
make it hard to create a concerted focus on the problem, as the next section will discuss.

In addition to its inherent conservatism, the international education community's relative failure to adapt to these trends and to innovate can be traced to the weakening institutional environment at the international level. For a variety of reasons, UNESCO has not exercised leadership as it did from its foundation following World War II until the 1980s. These reasons include its increasing politicisation (Burnett, 2011) and also, most recently, the serious resource issues that have resulted from the non-payment of USD 130 million of dues by the United States in response to the organisation's admission of Palestine.

Yet no other institution has stepped in to fill the partial void and the international institutional framework for new global initiatives in education is thus one of 'leaderless globalisation' (Rodrik, 2011): there are many important trends and developments but there is no effective mechanism for prioritising and guiding them. The World Bank has launched a number of research and benchmarking initiatives, and has clearly signalled the importance of learning by titling its current strategy document Learning for All, but the Bank has not tried, nor does it have the mandate, to lead the global community on education. The Global Partnership for Education is too much a financing mechanism and too focused on basic education to perform this role. The regional development banks have largely moved away from basic education to focus more on higher and technical education. The United Nations International Children's Emergency Fund (UNICEF) has continued to concentrate particularly on equity and on the disadvantaged, though it is increasingly interested in innovation. The UN Secretary-General has also tried to fill the gap, with the launch of the Education First initiative, and the appointment of former UK prime minister Gordon Brown as a Special Envoy. A further interesting development is the expansion of the Organisation for Economic Co-operation and Development's (OECD) education activities towards developing countries, especially middleincome ones, which are not OECD members. None of these other institutional efforts has resulted in clear leadership at the international level. Rather there is a plethora of activity but insufficient coordination.

The situation is further compounded by increased globalisation. Countries increasingly understand that their economic futures depend in large part on the skills of their labour forces, and so in turn on their education systems. Ideally this should lead to both competition and cooperation around education. 
Countries have yet to translate this into effective international cooperation; major emerging economies such as Brazil, China, India, and South Africa still exercise their influence as individual countries rather than through international institutions. The fact that most of these middle-income countries found the 2000 education MDGs and EFA goals largely irrelevant to them has also contributed to their reluctance to engage. A further important development is the entry of many new actors onto the international education scene, especially private foundations (such as the Hewlett and MasterCard foundations), private corporations (such as Pearson) - both directly and through their corporate social responsibility (CSR) functions - and non-traditional donors such as Qatar and China (see King, Chapter 8 in this volume). CSR is particularly interesting - in both South Africa and India it is now compulsory and, in both countries, education appears to be one of the major sectors receiving finance through this modality, as much as 40 per cent of the total in South Africa. Thus one of the major responses to the learning crisis, the establishment of a Learning Metrics Task Force, run jointly by the Brookings Institution and the UNESCO Institute for Statistics, has been driven and financed largely by private funding from foundations in OECD countries, resulting in high quality work that faces serious issues of wider legitimacy.

\section{The Data and Evaluation Revolution}

It is now a commonplace to talk about the impact of the data revolution on development. This largely consists of the availability of major datasets, especially internationally comparable ones, and the application of rigorous evaluation techniques.

These developments have affected education in four major ways. First, educational data have traditionally largely been administrative data, taken from school and institutional records. Increasingly, however, with the Living Standards Measurement Study (LSMS) ${ }^{1}$ and Multiple Indicator Cluster Surveys (MICS), ${ }^{2}$ population-based data have become available-it is instructive to

1 Established by the Development Research Group in order to improve the quality of household data collection in developing countries, http://econ.worldbank.org/WBSITE/EXTERNAL/ EXTDEC/EXTRESEARCH/EXTLSMS/0,,contentMDK:21478196 menuPK:3359066 pagePK: 64168445 piPK:64168309 theSitePK:3358997,00.html (accessed on 23 May 2014).

2 In order to fill gaps for monitoring the situation for women and children, UNICEF is assisting countries in the collection and analysis of data, http://www.unicef.org/statistics/ index_24302.html (accessed on 23 May 2014). 
compare the current EFA Global Monitoring Report with the early ones of a decade ago and to see this evolution of sources. Nonetheless, as discussions in the Learning Metrics Task Force have shown, there is still some reluctance to use population-based rather than administrative data, in part because of issues of control of such data. Departments and ministries of education tend to control administrative data more than they do population-based surveys.

Second, the OECD's Programme for International Student Assessment (PISA) ${ }^{3}$ and other international assessments such as the Trends in International Mathematics and Science Study (TIMSS) and the Progress in International Reading Literacy Study (PIRLS) ${ }^{4}$ have steadily increased their country coverage and are no longer confined just to OECD countries. PISA has been the most influential, comparing standardised measures of learning among 15-year olds across countries. These have reinforced the focus on learning and stimulated important action in some countries, the most recent example being Vietnam, which has improved very rapidly. Other countries have been provoked by their relatively poor rankings to try to take action; Thailand, for example, has recently established the Quality Learning Foundation to promote innovation and quality in its public schools following its ranking well below where it feels it should be as an upper-middle income country.

Third, and less positively, there remains a considerable reluctance to use evidence in education to determine 'what works'. OECD analysis of PISA results, for example, points towards important steps that can be taken to improve equity in learning; randomised controlled trials in education, all documented by the World Bank, show many things, including for example the importance of remediation; and there are examples of countries, such as Vietnam and South Korea, which have made tremendous progress with both enrolments and learning. Yet there remains a strong reluctance in the educational community to apply this evidence, as reflected in statements that education is not just about cognitive learning and that there is a danger of teaching to the test if excessive attention is placed on such assessments. These statements, while true, are disappointing; they appear to be the reactions of a conservative sector to data that show it has enormous scope to improve.

Fourth, there is the very interesting development of citizen-led assessments of learning, pioneered in India by the Annual Status of Education Report (ASER) and now applied also in Kenya, Mali, Mexico, Pakistan, Senegal, Tanzania, and Uganda. These assessments, so far carried out only at primary level, reinforce the opinion that there are major challenges in basic reading

3 http://www.oecd.org/pisa/ (accessed on 28 May 2014).

4 http://timssandpirls.bc.edu/ (accessed on 28 May 2014). 
and mathematics; what is still unknown is to what extent resulting public and parental pressure will lead to reform.

\section{$5 \quad$ Conclusion}

This short chapter has outlined some of the major developments in international education. It has highlighted both progress made and the huge challenges that remain, especially around learning. It has noted important data developments but the sector's reluctance to embrace them, reflecting its inherent conservatism that is seen also in the relative failure to innovate, at least on a major scale. It has observed the institutional weakness present at the international level.

What should priorities be in this situation? What should the international community focus on?

Five key areas seem most important. First, there is already a vast amount of evidence but a reluctance to apply it - efforts should be stepped up to diffuse this evidence and to compare countries' practices and reactions to what is known. Second, innovation should be strongly encouraged in education systems, to make them more effective and more relevant-secondary education being a good place to start with its out-of-date curricula and increasing irrelevance to the labour force. Third, international funding, declining though it is, should target more those countries in greatest need. Fourth, assessment, benchmarking, and evaluation should be further encouraged in the full recognition that cognitive achievement is not the only purpose of education. Fifth, and most difficult probably, international actors should try to develop an effective new international governance system for international education-but this may require leadership from outside the education sector.

\section{References}

Bird, K. and K. Higgins (2011) Stopping the Intergenerational transmission of poverty: Research highlights and policy recommendations, Working Paper 214 (Manchester: Chronic Poverty Research Centre).

Burnett, N. (2011) 'UNESCO Education: Political or Technical? Reflections on Recent Experience', International Journal of Educational Development, 31, pp. 315-318.

Colclough, C., G. Kingdon and H.A. Patrinos (2009) The Pattern of Returns to Education and Its Implications, Policy Brief 4 (Cambridge, UK: Research Consortium on Educational Outcomes and Poverty). 
Day A.L., C. Mcloughlin, M. Aslam, J. Engel, J. Wales, S. Rawal, R. Batley, G. Kingdon, S. Nicolai and P. Rose (2014) The Role and Impact of Private Schools in Developing Countries, Education Rigorous Literature Review (London: UK Department for International Development).

Feinstein, L., R. Sabates, T. Anderson, A. Sorhaindo, and C. Hammond (2006) 'What are the Effects of Education on Health?' in Desjardins, R. and T. Schuller (eds.) Measuring the Effects of Education on Health and Civic Engagement-Proceedings of the Copenhagen Symposium (Paris: OECD), pp. 171-313.

Hanushek, E. and L. Woessman (2010) How Much Do Educational Outcomes Matter in OECD Countries?, NBER Working Paper 16515, (Cambridge, MA: National Bureau of Economic Research).

Heyneman, S.P. (2003) 'Education, Social Cohesion and the Future Role of International Organizations', Peabody Journal of Education, 78(3), pp. 25-38.

Lowenstein, C., M. Ziswiler, K. Bidwell and L. Watine (2014) Exploring Early Education Programs in Peri-Urban Settings in Africa: Summary Findings from Lagos, Nigeria (Zurich: UBS Optimus Foundation).

Majgaarden, K. and A. Mingat (2012) Education in Sub-Saharan Africa: A Comparative Analysis, World Bank Study 70979 (Washington, D.C.: The World Bank).

Mertaugh, M.T., E.Y. Jimenez and H.A. Patrinos (2009) The Global Challenge in Basic Education: Why Continued Investment in Basic Education is Important (Washington, D.C.: The World Bank).

Psacharopolous, G. and H.A. Patrinos (2004) 'Returns to Investment in Education: A Further Update?, Education Economics, 12(2), pp. 111-134.

Rodrik, D. (2011) The Globalization Paradox: Democracy and the Future of the World Economy (New York and London: Norton).

Soares, R.R. (2004) 'Development, crime and punishment: accounting for the international differences in crime rates', Journal of Development Economics, 73, pp. 155-184.

UNESCO (2013) Education for All Global Monitoring Report (Paris: UNESCO).

- (2002) Education for All Global Monitoring Report (Paris: UNESCO). 